\title{
Noc Walpurgi (The Walpurgis Night): A New Variation on the Theme of the Holocaust. Several Suggestions as for the Future Reception of the Film
}

\author{
Don't ask why all this time I never spoke. \\ Wordless am I, \\ and won't say anything. \\ And silence reigns because the bedrock broke, \\ no word redeems; \\ one only speaks in dreams. \\ A smiling sun the sleeper's images evoke. \\ Times marches on; \\ the final difference is none. \\ The word expired when that world awoke.
}

Karl Kraus ${ }^{1}$

\begin{abstract}
Skibska Anna Maria, Noc Walpurgi (The Walpurgis Night): A New Variation on the Theme of the Holocaust. Several Suggestions as for the Future Reception of the Film. "Poznańskie Studia Slawistyczne" 12. Poznań 2017. Publishing House of the Poznań Society for the Advancement of the Arts and Sciences, pp. 283-297. ISSN 2084-3011.
\end{abstract}

In the essay, I make an attempt to present several ways, in which the Western canon of literature, music, and cinema has influenced Noc Walpurgi. With regard to this, Marcin Bortkiewicz's film turns out to be a work made of many citations, in Walter Benjamin's terms, drawn extensively on Goethe's Faust, Mann's The Magic Mountain, Bulgakov's The Master and Margarita, Wagner's Ride of the Valkyries, and Puccini's Turandot, and the film noir poetics elaborated in the 40s

\footnotetext{
${ }^{1}$ The quotation is derived from a monograph by Harry Zohn devoted to the rather controversial biography of the famous Vienna satirist (Zohn 1997: 54), whose life is also presented in detail by Edward Timms in his two-part Karl Kraus: Apocalyptic Satirist (for further information, v. Timms 1989, 2005). In the second part of Timms's work on Kraus, there is a commentary regarding Kraus's analysis of Nazi ideology contained in his Third Walpurgis Night, which turned out to be the culmination of the satirist's career.
} 
and 50s of the twentieth century. Based on Magdalena Gauer's monodrama Diva, Noc Walpurgi illuminates in the highly expressionist manner an alienated, cynical, and despotic psyche of Nora Sadler, a great opera singer, who is tormented by the Holocaust past.

KEYwORDS: diva; opera; citation; art; Holocaust

\section{A short introduction}

In the initial part of the essay, a paradoxical aspect of the titular theme must be revealed, and subsequently commented from the view-point of a certain cultural procedure, for reason of which I tend to consider the genocide crime as a necessary and piercing act of the circulating, or still returning commemoration. The motif of the Holocaust, constantly repeated by the contemporary generations of artists, should be, therefore, regarded as an antithetical contamination of the singular event with its various representations enabling this event's consolidation, which must be assumed as consolidation-in-work ${ }^{2}$. The essential value of the current representations is to confirm an overwhelming need for substitution. Furthermore, the substitution itself establishes a sort of "security system", in which realm the genocide theme stands for a serious warning against the real possibility concerning the repetition of the past ${ }^{3}$, and it preserves the absent experience of those who were slaughtered and those who survived the horror of the extermination. In order to retain this absent experience (the number of the survivors drastically diminishes all the time), which shapes our view of the world by constituting the phenomenon of the so-called post-memory, European (and world) culture keeps exploiting the Holocaust theme.

\footnotetext{
${ }^{2}$ Consolidation-in-work itself must be concentrated on the future that is to come, and this future, assumed as unknown yet more than expected one, should be always determined by the past.

${ }^{3}$ It is worth emphasizing that this repetition is conditioned by the double process of repression and suppression (in their psychoanalytical sense) elaborated by Jacques Derrida in his reflections on the archive phenomenon, in which the thinker states that "Without the irrepressible, that is to say, only suppressible and repressible, force and authority of this transgenerational memory, the problem of which we speak, would be dissolved and resolved in advance. There would no longer be any essential history of culture, there would no longer be any question of memory and of archive (...), and one would no longer even understand howe an ancestor can speak within us, to speak in such an unheimlich, 'uncanny' fashion, to his or her ghosts" (Derrida 1996: 35-36).
} 
Among a growing number of its representations, one must recognize Noc Walpurgi (The Walpurgis Night), a debut film of Marcin Bortkiewicz, which was premiered in Poland in September 2015. Thus the central part of the essay is devoted to this film, since it attempts to undertake an intriguing, intertextual and perverse play with the genocide motif, in which a fictional existence of Nora Sedler (the main character of Bortkiewicz's film starring a famous opera singer) is tragically embroiled.

\title{
2. The film: a brief glance at the course of events ${ }^{4}$
}

\author{
I am the spirit, ever, that denies! \\ And rightly so: since everything created, \\ In turn deserves to be annihilated; \\ Better if nothing came to be, \\ So all that you call Sin, you see, \\ Destruction, in short, what you've meant \\ By Evil is my true element.
}

(Goethe 2003)

The Polish premiere of Noc Walpurgi took place after the film festival in Gdynia on the $25^{\text {th }}$ of September $2015^{5}$. The storyline, derived from the monodrama Diva by Magdalena Gauer ${ }^{6}$, is very simple and consists

\footnotetext{
${ }^{4}$ There are at least two important reasons, for which this course of events should be shortly discussed: on the one hand, the film hasn't been distributed yet neither in cinema nor television (due to a presumed lack of agreement between the film makers and distributors), and because of that it couldn't have reached an expected level of the audience's attention; on the other, based on the theatre monodrama, it consists of events mirrored in the main character's memory rather than of the presented action demanding interpretation that regards mainly the aesthetical means of expression.

${ }^{5}$ The main prize that is, the famous Gold Lions has gone to Małgorzata Szumowska for the film entitled Body/Ciało, however, the jury of the $40^{\text {th }}$ edition of Gdynia Film Festival has also favoured the debut work of Marcin Bortkiewicz.

${ }^{6}$ Magdalena Gauer, for whom Diva also was a literary debut, decided to cooperate with Stanisław Otto Miedziewski from the Theatre Rondo, who relayed on a different source of inspiration too, namely, Dzienniki Etki Daum by Elżbieta Cherezińska. Gauer states that these documents "są niezwykłym wejściem do getta łódzkiego, oswojeniem tej przerażającej przestrzeni. Znalazłam tam informację o transportach Żydów z Europy Zachodniej, wśród których byli wybitni artyści, ludzie nauki, kultury, z Wiednia, Berlina, Pragi. Zatem punktem wyjścia był dla mnie poruszający tekst Elżbiety Cherezińskiej i jej wnikliwe, oryginalne
} 
in an exposition of Nora Sedler, played expressionistically by Małgorzata Zajączkowska ${ }^{7}$. In the original script, created by Gauer for the local Theatre Rondo in Słupsk and staged for the first time in $2010^{8}$, the fictional character of the titular diva was played by Wioletta Komar. Her significant role, maintained in the minimalistic style which was expressed or emphasized by the consequent presence of black and white, won recognition not only in Poland. Only a year after the play's premiere, Diva was staged in New York bringing a series of prizes for the actress ${ }^{9}$. According to the inventor of the fictional yet highly probable character,

Nora jest jak soczewka, w której skupiają się losy artystów, którzy przeszli przez getto. Stanisławowi Miedziewskiemu [the monodrama's director - A.M.S.] bardzo spodobało się to, że pokażę Holocaust inaczej. Przez pryzmat śpiewaczki i muzyki, która wcale nie musi dawać ocalenia, a może być nawet narzędziem mordu. „Diva” jest kompilacją tragedii, groteski, komedii. Sytuacje bardzo dramatyczne, wywołujące łzy, łamane są komizmem, czasem bardzo okrutnym. Moja Nora opowiada nie tylko o pobycie w getcie, zresztą niewiele o tym mówi, relacjonuje też swoje występy na największych scenach operowych świata, snuje anegdoty, opowiada o współczesnej kulturze, sztuce, jest złośliwa, fascynująca, ale też cyniczna i wzruszająca - dzięki temu łatwiej było mi uniknąć patosu ${ }^{10}$.

But let us turn back to the film, which should be considered as a loose adaptation of the commented monodrama. From the very beginning, the spectators are squeezed into the format of a voyeur since their encounter with the singer occurs "off the stage", in the black and white scenery of her

spojrzenie na rzeczywistość getta. Zaczęłam zastanawiać się, kim byli, jak czuli się w tym świecie wybitni muzycy, filozofowie, pisarze. Co dzieje się ze sztuką, artystą w świecie Holocaustu? Czy sztuka jest ocaleniem? Czy muzyka może być narzędziem tortur?” (v. Marciniak 2011). To this must be added something else: Bortkiewicz's film introduces itself as a work of the whole series of mediations initiated by the lack of the source material. Thus it is said that at the begining of the plot there is a verbal relation made by Rumkowsky's secretary, which is orally reconstructed by her son accidentally met on the train by Cherezińska. The authoress makes use of this relations in Dzienniki Etki Baum, which are the basis for Gauer's monodrama subsequently fundamental for Noc Walpurgi by Bortkiewicz.

${ }^{7}$ For more information, v. Steciak 2015; Ciechowski 2016.

${ }^{8}$ For more information, consult the interview granted by Gauer to the „Głos Koszaliński” 01.01.2012: Z Kołobrzegu na Brodway.

${ }^{9}$ It's worth emphasizing that in 2011 Komar playing Gauer's diva was regarded the best actress of The 2nd United Solo Theatre Festival in New York. For more information, consult Sukces na Broadwayu.

${ }^{10} \mathrm{~V}$. Marciniak 2011. 
dressing room ${ }^{11}$. Nora Sedler has just finished playing her opera role and attempts to immerse herself in a relaxing privacy, which is to be disturbed by some unexpected circumstances.

Due to a theatrical manner of the film (its makers admit that they were very anxious about the movie status for there was a serious fear that it would transform into another theatre of television), one has to concentrate on the initial details which traditionally manifest the basic, however, essential data of the presented event: it's the evening of the $30^{\text {th }}$ of April 1969; the action takes place in the Opera Theatre in Switzerland ${ }^{12}$. A young journalist Robert (aged 27), played by Philippe Tłokiński (a promising actor of the Polish-French origin), visits the theatre in order to conduct an interview with the great opera singer Nora Sedler (aged 56). They meet in her dressing room after the modern or avant-garde adaptation of Puccini's Turandot, in which the singer plays her role in a grotesque white costume of the scuba-diver. The costume itself spectacularly reveals an aesthetical choice made by Bortkiewicz, who tries in this way to indicate the tragicomic perspective of his work. This perspective is rendered by a peculiar act of deformation of the pathetic scene, which concerns the entering the stage by the artist ${ }^{13}$. It's worth noticing that the surrealistic poetics of hyperbolic deformation is consequently maintained in the whole movie.

The very first reaction of the despotic and cynical diva to the unexpected guest is her attempt to get rid of the intruder by the Polish unparliamentary word "spierdalaj" ('fuck off'). The scene itself casts some additional light on the artist's stereotype assuming the presence of proper language standards. In spite of her initial hostility, Nora finally decides to grant the interview to Robert, which soon transforms into a sort of deep-laid game. Through an intriguing and permanent process

${ }^{11}$ According to the film makers, this scenery resulted from some external factors related with the impossibility of any changes to the rented interior (decorated in undesirable colours), in which the film was realized.

${ }^{12}$ The choice of the place has its own meaning due to the historical-political aspects of the Swiss neutrality during the Second World War. Another signal of the film's engagement in the historical correctness is one of the initial scenes, in which Nora dismisses her young dressing maid of Italian origin (played by Monika Mariotti) because she mentions Polish concentration camps.

${ }^{13}$ The assumed incongruity extremely well highlights the tragicomic character of the film, of which creators attempt to avoid pathos effects. 
of drawing the young man to herself in order to push him subsequently away, the diva provokes an erotic tension that from now on is to determine a rather bizarre relationship gradually developing between the protagonists. Due to the journalist's Nordic appearance, Nora paradoxically begins to perceive Robert as an incarnation of her former Nazi torturer. The unbearable activity of Nora's memory transports the spectators back to the years of the Second World War that is, to the autumn 1942, when the singer as a Polish Jew landed in Litzmannstadt Ghetto in Łódź. Her survival, first in the ghetto and later in Auschwitz, was directly connected with her singing skills, which, however, forced her to participate in the sadistic sexual orgies staged by Gestapo officers. Abused physically and mentally, constantly exposed to gang rape, naked and bleeding badly, Nora all the time had to perform the famous opera arias. In the privacy of her dressing room, the great artist, whose current attitude towards music is determined by hatre ${ }^{14}$, returns in a masochistic manner to all those horrible events from the past, into which she now drags the young journalist. The diva demands a cruel staging of that past from Robert, who surprisingly agrees to this overwhelming and horrifying game. In order to understand the journalist's decision, one has to recognize his real motivation that is hidden in the form of the interview. It turns out that Robert is a beginning composer, who dreams on a great career in the musical world, which simply could quicken at the famous opera singer's side. The demonic and perverse game, imposed by Nora's despotic will on Robert, results nevertheless in an astonishing denouement, according to which the journalist / composer introduces himself as a son of the diva. Born during the War in Litzmannstadt Ghetto, Robert had been adopted by some Polish family before Nora was transferred to Auschwitz. The scene of recognition, constructed by a clear analogy to the Greek ancient tragedy ${ }^{15}$, entirely demolishes Nora's ambiguous scenario, which

\footnotetext{
${ }^{14}$ Nora's attitude is revealed in the beginning of the interview initiated by the journalist's question: “- Dziewiętnaście lat temu w jednym z wywiadów z 1950 roku powiedziała Pani, że nienawidzi muzyki. Dlaczego Pani cały czas śpiewa"? The only answer of the cynical diva is: ,- Bo to jest świetny sposób na zarabianie pieniędzy”.

${ }^{15} \mathrm{I}$ am referring here to the event of anagnorisis conventionally comprehended as a moment in a plot where the main character recognizes his/her true nature, identity, or situation leading to the resolution of the story.
} 
previously dismayed the planned interview, although the finally exposed suggestion regarding the dark atmosphere of incest deeply sets in the spectators' consciousness. Moreover, the witnesses to this gloomy series of events are to face the irony of coincidence, without which the aesthetical dominant feature of the film would be rather abortive or pointless, since for its full effect the tragicomic view-point demands such irony to occur ${ }^{16}$. The tragic irony of this tragicomic work remains, therefore, a fusion of the components, which from the aesthetical perspective are at variance with themselves, yet eventually it always evokes the tragedy (Łaguna 1984: 59).

\section{Layers of contexts}

But think! The mount is magically mad today, And if a will o' the wisp should lead the way, You mustn't judge things too precisely.

(Goethe 2003)

Most of reflections, which are to bear the essentially unbearable burden of the Holocaust, have to confront the phrase of "the banality of evil", coined by Hannah Arendt while her reporting of the 1961 Adolf Eichmann trial for "The New Yorker" ${ }^{17}$. Despite a considerable controversy and even animosity towards Arendt in the world Jewish community (Elon 2006: 21), "the banality of evil" manages to unveil a different and up to this time uncommon origin of the mass murder excess, according to which Eichmann's deeds in particular, and the Holocaust crime in general result from stupid-

${ }^{16}$ „Nie jest (...) tragikomizm pojęciem estetycznym, jest to raczej opisowe określenie struktury wewnętrznej niezwykle spójnej, struktury właśnie jako całości tragicznej (...) W wyższym sensie, poprzez zaprzeczenie tragizmu" (Laguna 1984: 60-61).

${ }^{17}$ „Despite all the efforts of the prosecution, everybody could see that this man [Eichmann - A.M.S.] was not a 'monster,' but it was difficult indeed to suspect that he was clown. And since this suspicion would have been fatal to the entire enterprise, and was also rather hard to sustain in view of the sufferings he and his like had caused to millions of people, his worst clowneries were hardly noticed and almost never reported" (Arendt 1965: 55). 
ity and thoughtlessness ${ }^{18}$. Human stupidity and thoughtlessness, which are wholly unexceptional, although they happened not to the pervert species of monsters but to the ordinary men like Eichmann himself. Regardless of the striking truthfulness of Arendt's comportment, the conclusive and somehow definite character of the banality of evil, which visibly tends to end up the Holocaust discussion, seems from the perspective of contemporary culture not very favourable, since it cannot offer a vivid and effective inspiration for the further realizations of the motif. For that reason, the new generations of artists keep exploring the Western cultural heritage in order to look for attractive forms of expression, which are to commemorate the crime of genocide. Thus the issue of the so called post-memory becomes a question of intertextual activities enabling a difficult constitution of the reliable namely, performative representation of the Holocaust.

The title of Bortkiewicz's film clearly refers to the recognized phenomenon of the Walpurgis Night, which originates from Germanic folklore tradition: its name is explained in the following words:

The evidence suggests that the Walpurgis Night acquired its name through the convergence of several figures and dates that are at turn loosely related or unrelated: a pagan goddess (or several pagan goddesses) whose history antedates the documented Walpurgis Night legends; an eponymous figure associated with the cult of Woutan; the life and work of the eight-century Anglo-Saxon missionary who worked in Saxony; the phenomena that led to her canonization; the longstanding lore of the Brocken as a site of witches' Sabbaths; and the Drang nach Osten (eastward push) by which Charlemagne's empire expanded and was consolidated - and finally, the date of May 1, the day of Walpurgis's canonization, her feast day, the date of Boniface's promotion to Archbishop of Mainz and Primate of Germany, and the date traditionally assigned to the celebration of springtime (Cooper 2007: 10).

Let me remind that the significant date of the Witches' Night also appears in Bortkiewicz's movie. In its symbolic interpretation, the date itself means the end of winter that is in other words, Death, and the beginning of Life, its magnificent resurrection rendered by the advent of spring. Thus in the manner of some indirect allusion, The Walpurgis Night makes a discreet attempt to suggest this deep-rooted need for such transformation which may

18 "Imbecility; imbecility in the vast majority of men, at all times, and, even in heroes, in all but certain eminent moments, victims of gravity, custom, and fear," as Ralph Waldo Emerson states the whole century before Arendt's recognition (Emerson 1869: 14). 
be equipped with an inaccurate yet necessary presence of hope ${ }^{19}$. What is more, according to the original background of the German folklore tradition, there is a phenomenon known under the name of the Brocken Spectre, described by Oxford Dictionary of Phrase and Fable as "a magnified shadow of an observer, surrounded by rainbow-like bands, thrown onto a bank of cloud in high mountain areas when the sun is low" (Knowles 2006). Besides its magical properties, the unspeakable and irrational feature of the spectre one can easily apply to the dangerously grotesque atmosphere of Bortkiewicz's film: on the one hand, it may refer to the dark times, encapsulated in Nora's individual memory, and on the other, to the mystery that keeps hanging in the air, right above the heads of the protagonists. But, as we have already known, one "mustn't judge the things too precisely". Furthermore, the motif of the magnified shadow might be also explicated in a broader, intertextual sense, in conformity with which it manifests itself as the whole cultural heritage along with its various discursive and aesthetical solutions. They simply remain in the sphere of our disposition: Bortkiewicz seems to remind us that the theme of the Holocaust, if it is going to preserve in our multicultural world, demands being enriched by the new manners of articulation, new codes, which, however, must be constructed from the elements already created by the Western civilization. What is more, the reservoir of forms and themes, motifs and conventions must be conceived from the view-point of our contemporary attitude towards the past. In her significant study devoted to Walter Benjamin, Hannah Arendt comments on his discovery regarding the past, of which critical situation is a result of the irreversible double loss of tradition and of authority (Arendt 1968). For that reason, the status of the archive faces the unavoidable transformation, according to which it becomes a collection of schemes awaiting their repetition. Thus the only relation with the past is conditioned by the possibility of citing, which only confirms the ironic poetics of various borrowings and fragments that shape our current inter-textual and multi-media culture. With regard to this, each piece of art should be perceived as a mosaic of quotations (in Mikhail Bakhtin's terms Burzyńska, Markowski 2007: 160) incorporated into a new configurations, designs, or patterns.

\footnotetext{
${ }^{19}$ The phrase 'inaccurate yet necessary' is derived from Derrida's idiom, and is related with the necessary presence of the inaccurate word (Spivak 1997: 13-15).
} 
The phenomenon of the Walpurgis Night, which reflects evil streaked with good, despair with hope, death with life, irrational with rational, darkness with light, sublime with counter-sublime, tragedy with comedy, becomes, therefore, a crucial scene of instruction, still valid instruction although it cannot be regarded as the primary one any more ${ }^{20}$. Due to this, one has to reconsider the archives of literary tradition, in which the analysed motif is deeply set. These archives have been established by the very strong precursors (in Harold Bloom's terms ${ }^{21}$ ): among of them in the first place the names of Goethe, Bulgakov, and Thomas Mann should be listed since their great works have preserved the phenomenon of the Walpurgis Night together with its necessary reinterpretation ${ }^{22}$. In both parts of Faust, of which essential presence has been already emphasized in the aforementioned epigraphs, the commented motif is related with the tempestuous birth of the modern subjectivity exposed in the individual development of the protagonist:

What this Faust wants for himself is a dynamic process that will include every mode of human experience, joy and misery alike, and that will assimilate them all into his self's unending growth; even the self's destruction will be an integral part of its development (Berman 1988: 40).

Yet this dialectical process of development is based not only on the self's destruction: it also demands the other's destruction that is perfectly expressed by the case of Gretchen and, moreover, anticipates the catastrophic thought, which is to announce the end of the modern experience namely, the Holocaust itself. Regardless of the so-called historical background, and according to the Jewish perspective every single death caused by the other means the extinction of the whole human world. Only for that reason, all the activities undertaken by individuals must necessarily occur in the horizon of the never ending Apocalypse, since the very horizon

${ }^{20}$ The cultural processes of reiteration always assume difference, which effaces the socalled source materials (texts, documents, etc.), yet their real force of signification engenders from the ironic distortion of the previous contexts.

${ }^{21}$ The precursors themselves are the authors of many maps of misreading, which are to determine the so-called anxiety of influence (Bloom 2003: 125-143).

${ }^{22}$ Besides Faust, I am referring to The Magic Mountain (1924) by Thomas Mann, and to The Master and Margarita by Mikhail Bulgakov. 
conditions the conduct of life, to use the initial utterance of the famous late work of Ralph Waldo Emerson ${ }^{23}$.

In The Magic Mountain, the Walpurgis Night provides the last chapter of the first part of the novel with the title, and finds its culmination in the masquerade organized in the Berghov sanatorium because of the Carnival feast. From Bortkiewicz film's perspective, the scenes presented in this chapter seem important due to the sophisticated dialogue between Hans Castorp and Clavdia Chauchat (almost in total held in French), during which Clavdia keeps mocking her young admirer, for whom she is the main reason to prolong his stay in the sanatorium. What is more, her derisive manner of conversation with Castorp is additionally intensified by her provocative gestures made with a pencil. Considered as a representation of erotic temptation, lust, and love, Clavdia is compared to Lilith by Settembrini, who himself might be perceived as an incarnation of Goethe's Mephisto competing with Naphta for Castorp's soul. For reason of her extravagant ambivalence, at the same time streaked with the ironic humour and nameless danger, Chauchat can be also regarded as a model realization of femme fatal announcing the conventional female character of the film noir (I will return to this issue in the last passages of my essay), which clearly determines Nora's manners of acting and behaviour (along with diva's sneering attitude towards Robert ${ }^{24}$.

In the well-known (23.) chapter of The Master and Margarita, entitled "The Spring Ball of the Full Moon" ${ }^{25}$ " and being a reminiscent of Goethe's scenes regarding the Walpurgis Night, Margarita as a queen Margot encounters Gretchen's incarnation named Frieda, who as well as the rest of more or less significant guests arrives the ball from the world of the dead (all of them appear in their grotesque coffins). In addition, Frieda's posthumous fate is to live in terrible tribulation, which is a result of the murder

${ }^{23}$ It's worth reminding one of his statements, according to which „The secret of the world is, the tie between person and event. Person make event and event person" (Emerson 1869: 10).

${ }^{24}$ Bortkiewicz admits that the quotation from Mann's Walpurgis Night (one of the chapters of the novel The Magic Mountain) is to render the oneiric atmosphere making the film protagonists relationship more vague and mysterious - v. Ryćkowska 2015.

${ }^{25}$ In this chapter, Bulgakov refers to the historical event of The Spring Festival at Spaso Hause, which had been the Moscow residence of the U.S. Ambassador to the Soviet Union (Cleary 2008: 18-20). 
committed by the character on her new-born child what also resembles the crime of infanticide attributed to Gretchen. ${ }^{26}$ As was already mentioned, Nora on the contrary to her literary precursors has managed to save her baby-boy's life that, however, in her particular case announces a similar to those of Gretchen and Frieda feeling of torment endured in a total loneliness sharply juxtaposed with diva's "divine" existence.

Another confirmation of Bortkiewicz's commitment to the heritage of European culture is the initial context of the opera, appropriately intensified by the musical background of Wagner's work. The context refers to Turandot, the last and unfinished opera in three acts by Giacomo Puccini, completed after his death in 1924 by Franco Alfano in 1926. The opera is based on the text by Carlo Gozzi (it's worth underlining that the very same plot under the very same title was also elaborated by Friedrich Schiller and subsequently transferred onto the stage by Goethe), who tried to mirror Haft Peykar (The Seven Beauties), written in the $12^{\text {th }}$ century by the Persian poet Nizami, the author of the original story of Turan-Dokth (daughter of Turan) ${ }^{27}$. The titular character is the Cold Princess, who is known from refusing (clearly resembling the act of the initial refusal to grant the interview to Robert!) to get married. In the opera's libretto (the story itself is set in China), the main plot concerns the Cold Princess and the Prince Calaf, who falls in love with her. In order to marry Turandot, the prince, as well as all the former suitors, has to solve three riddles (this part of the Persian fable clearly resembles the well-known motif of the mythical monster Sphinx from the disastrous biography of Oedipus): any wrong answer results in death. In spite of the test, which Calaf emerges victorious, the Princess doesn't want to change her mind and still refuses to become a wife to the Prince. In answer, Calaf proposes the only one solution: if she is able to learn his name before dawn the next day, then at daybreak he will die. I have decided to bring the libretto's story back in order to emphasize the intertextual relationship between Puccini's opera and Bortkiewicz's

\footnotetext{
${ }^{26}$ Goethe's Gretchen was to drown her child in the pond nearby her house while Bulgakov's Frieda ,when she worked in a cafe, the owner once invited her to the pantry, and nine months later she gave birth to a boy, took him to the forest, stuffed the handkerchief into his mouth, and then buried the boy in the ground. At the trial she said she had no way of feeding the child", according to Koroviev's explanation given to Margarita (Bulgakov 1992: 355).

${ }^{27}$ For further information, cf. Weaver, Puccini 1994: 375-376.
} 
film: its focal point refers to the scene of recognition, the fatal scene that announces death. In the final episodes of Noc Walpurgi, Nora learns, metaphorically and literally speaking, Robert's real name, however, the film ends before the expected conclusion. The spectators are, therefore, left with a lack of the so-called definite answer, which is to remain, as I presume, in accordance with the film makers' intention. Their choice also casts light on another purpose suggested by the movie, which may be comprehended as an introduction to the secondary discussion on the tension between knowledge and non-knowledge. The tension itself is stressed by the presence of aposiopesis, the figure which is to free from such restrictions like a moral judgement of the protagonists, etc. Manifested by the overwhelming silence, which is the only response of the spectators to the end of the film, this aposiopesis remains, however, in the conflict with the world of music enabled to rescue from suffering or death. Regardless of the ambiguous or ambivalent status of music (culture), Bortkiewicz does not renounce musical quotations following in this his literary ancestors ${ }^{28}$.

Noc Walpurgi, which reflects rather well Benjamin's formula of "reception in a state of distraction" (Benjamin 1999: 233), remains in the sphere of influence of the noir (or neo-noir) film deeply rooted in the tradition of German Expressionism. This convention has a clear effect on the conception regarding lights and shadows interplay (chiaroscuro), perfectly rendered in Bortkiewicz's film by Andrzej Wojciechowski. His original and somehow paradoxical idea is to present the evolution of light through its growing implosion resulted in a series of singular photons ravaged by the darkness in the last shots of Noc Walpurgi ${ }^{29}$. Nora's creation, as it was mentioned before, also testifies the noir film inspiration, since it is "alienated," and "filled with existential bitterness" (Naremore 2008: 25; Silver, Ward 1992: 35) associated with a sense of heightened anxiety, which is to

${ }^{28}$ Especially Mann, who in The Magic Mountain refers to Verdi's Aida, Schubert's Winter Journey, Wagner's Tristan and Iseult, and Debussy's Prelude to the Afternoon of a Faun. In Bulgakov, the presence of musical contexts seems much more distorted, since they are wholly submitted to the opaque, grotesque vision of the world, in which Johann Strauss (the Ball scene) attempts to conduct the jazz orchestra.

${ }^{29}$ For more details, v. Wojciechowski’s commentary in: Szczerość za szczerość. Blok VIII, <www.festiwalmlodzifilm> form 20.07.2015 (08.03.2016); v. also: Noc Walpurgi making of: <www.Culture.Pl>, (08.03.2016). 
reflect the Holocaust experience of the protagonist as well as the convoluted intrigue of the movie. Zajączkowka's diva clearly refers to Maria Callas along with her legendary biography, but it is Simone Signoret, the unquestionable star (of the Jewish origin) of the French noir film, who made an indelible impression on the Polish actress while she was preparing herself to the role of Nora Sadler. Thus in one of the interviews, Zajączkowska admits that

Callas miała głos i temperament, które pozwalały jej być totalnie bezkarną. Simone Signoret to kobieta $\mathrm{z}$ dużą klasą, niesłychanie silna: miała w sobie wielką tajemnicę, a środku duszę dziecka, zranionego ptaka. Dostrzegłam to nie w jej grze, ale twarzy (Ryćkowska 2015).

The diva's sensitivity, mutilated by the Holocaust, and deeply concealed under a veneer of cynical churlishness and overwhelming brutality, is also a result of the aforementioned inspirations, which inscribe themselves to the archive in order to shape the (unexpected) future of the past.

In any case, there would be no future without repetition and thus, as Freud might say (...), there is no future without the spectre of the oedipal violence that inscribes the superrepression into the archontic institution of the archive, in the position, the auto-position or the hetero-position of the One and unique, in the nomological arkhe. And the death drive. Without this evil, which is also archive fever, the desire and the disorder of the archive, there would be neither assignation nor consignation. For assignation is consignation (Derrida 1996: 80-81).

\section{References}

Arendt H., 1965, Eichmann in Jerusalem. A Report on the Banality of Evil, New York. Arendt H., 1968, Men in Dark Times, New York.

Benjamin W., 1999, Illuminations, introduction H. Arendt, trans. H. Zorn, London.

Berman M., 1988, All That Is Solid Melts Into Air. The Experience of Modernity, New York-London.

Bloom H., 2003, A Map of Misreading, with a new preface, Oxford-New York.

Bulgakov M., 1992, The Master and Margarita, trans. D. Burgin and K. Tiernan O'Connor, New York.

Burzyńska A., Markowski M.P., 2007, Teorie literatury XX wieku. Podręcznik, Kraków. Ciechowski Z., 2016, Dostałam rolę wymarzona. Z M. Zajączkowska rozmawia Z. Ciechowski, 17.06., <www.tylkotorun.pl>, 20.10.2016.

Cleary S., 2008, Spaso House, 75 years: A Short History, Swindon. 
Cooper J.M., 2007, Mendelssohn, Goethe, and the Walpurgis Night: The Heathen Muse in European Culture, 1700-1850, Rochester.

Christopher N., 1998, Somewhere in the Night: Film Noir and the American City, New York.

Derrida J., 1996, The Archive Fever: A Freudian Impression, trans. E. Prenowitz, Chicago-London.

Elon A., 2006, Introduction, in: H. Arendt, Eichmann in Jerusalem..., New York.

Emerson R.W., 1960, The Conduct of Life, Boston.

Goethe J.W., 2003, Faust, Part I \& Part II, trans. A.S. Kline, <www.poetryintranslation.com>, 8.03.2016.

Knowles E. (ed.), 2006, Oxford Dictionary of Phrase and Fable, $2^{\text {nd }}$ ed., <www.oxfordreference.com>, 10.12.2015.

Łaguna P., 1984, Ironia jako wyraz i jako postawa, Kraków.

Mann T., 1996, The Magic Mountain, trans. J.E. Woods, New York.

Marciniak I., 2011, Z Kołobrzegu na Broadway. Rozmowa z Magdalena Gauer, „Głos Koszaliński” No. 303, 30.12., <http://www.e-teatr.pl/pl/artykuly/130082,druk. html>, 10.12.2015.

Naremore J., 2008, More than Night: Film Noir in Its Contexts, Berkeley-Los Angeles-London.

Noc Walpurgi, 2015, directed Robert Bortkiewicz, script Magdalena Gauer, Robert Bortkiewicz, photography Andrzej Wojciechowski, music Marek Czerniewicz, Polski Instytut Sztuki Filmowej, PS Film, Aurora Films.

Ottoson R., 1981, A Reference Guide to the American Film Noir: 1940-1958, Metuchen-New York-London.

Power S., 2013, “A Problem From Hell”: America and the Age of Genocide, New York.

Ryćkowska M., 2015, Lubimy być bezkarni. O wspólnej pracy i najtrudniejszych momentach na planie filmu Noc Walpurgi M. Zajączkowska i M. Bortkiewicz rozmawiaja z M. Ryćkowska, 17.09., <www.nowyfolder.com>, 15.12.2015.

Silver A., Ward E., 1992, Film Noir: An Encyclopedic Reference to the American Style, $3^{\text {rd }}$ ed., Woodstock-New York.

Spivak G.C., 1996, Translator's Preface, in: J. Derrida, Of Grammatology, corrected edition, trans. G.C. Spivak, Baltimore-London.

Steciak M., 2015, Czekam na niespodzianki. Z M. Zajączkowska rozmawia M. Steciak, 07.08., <www.film.onet.pl>, 15.12.2015.

Sukces na Broadwayu, "Głos Koszaliński” No. 275, 28.11.2011.

Timms E., 1989, Karl Kraus: Apocalyptic Satirist: Culture and Catastrophe in Habsburg Vienna (1874-1918), New Haven-London.

Timms E., 2005, Karl Kraus: Apocalyptic Satirist: The Post-War Crisis and the Rise of the Swastika (1918-1936), New Haven-London.

Weaver W., Puccini S., (eds), 1994, The Puccini Companion, New York.

Zohn H., 1997, Karl Kraus and the Critics, Columbia. 